\title{
The oestrous cycle of the brown lemur, Lemur fulvus
}

\author{
Katharine J. Boskoff* \\ Department of Zoology, Duke University, Durham, North Carolina 27706, U.S.A.
}

\begin{abstract}
Summary. Examination of vaginal smears and observations of the colour and tumescence of the genitalia and discharge of mucus of 9 brown lemurs indicated that the oestrous cycle lasted for 30 days and that cycles occurred between September and July. The timing of cycles of females housed in visual isolation differed from that of females able to see other lemurs, indicating that the oestrous cycle in this species can be influenced by different housing conditions.
\end{abstract}

\section{Introduction}

The scarcity of prosimian primates in captivity and the rapid deterioration of their natural habitat emphasize the critical condition of these endangered species. Perpetuation of prosimians through successful husbandry demands a knowledge of their reproductive biology. For the lorisid and cheirogaleid groups a sizeable literature concerning reproduction has accumulated in recent decades (see Van Horn \& Eaton, 1978), but there is much less information about the lemurid species, the most endangered of the prosimians. For the genus Lemur, various aspects of mating behaviour and reproductive cycles in wild and captive animals have been described: Petter $(1962,1965)$ and PetterRousseaux $(1962,1964,1968)$ deal with several species, and Bogart, Cooper \& Benirschke (1977a) and Boskoff (1977) discuss $L$. macaco and $L$. variegatus, but the bulk of the literature concerns $L$. catta (Jolly, 1966, 1967; Evans \& Goy, 1968; Van Horn, 1975; Budnitz \& Dainis, 1975; Reynolds \& Van Horn, 1977; Bogart, Kumamoto \& Lasley, 1977b).

Lemur fulvus, however, has not been extensively studied; only mating behaviour has been described for captive and wild animals (Cowgill, Bishop, Andrew \& Hutchinson, 1962; Harrington, 1971, 1975; Sussman, 1972, 1975; Chandler, 1975; Vick \& Conley, 1976; Boskoff, 1978). The present study describes the oestrous cycle and its seasonality in captive brown lemurs.

\section{Materials and Methods}

The animals studied were females of the L. fulvus fulvus and $L$. fulvus rufus subspecies and their hybrids at the Duke University Primate Facility. Eight (8) lemurs were divided into two groups of four and the groups were matched by pairs with respect to subspecies, age and reproductive history. Each animal was housed individually, with each group in a rack of 4 cages. The two racks of cages were in the same room, separated by a black cloth curtain. Fluorescent white lights illuminated the room during the day, with daylength approximating the seasonal shift in sunrise and sunset. The two groups differed with respect to visual contact with other females. For Group A, visual contact was prevented by solid steel cage panels, but the lemurs in Group B could see one neighbouring lemur through a wire-mesh cage panel. All the animals could hear and smell the other females. A ninth female was housed with a male in another room.

At 09:00 $\mathrm{h}$ on Monday, Wednesday and Friday of each week from 9/9/74 to $8 / 21 / 75$, vaginal smears were obtained with a sterile cotton-tipped applicator. After air-drying overnight, the smears were fixed in methyl alcohol and stained with a Giemsa stain. Slides were examined at magnifications of $\times 40$ and $\times 200$ and descriptive and quantitative records were made. The entire slide was scanned for assessment of epithelial cell shape, cell nucleus size, presence and distribution of mucus, and general

* Present address: Zoological Society of San Diego, P.O. Box 551, San Diego, California 92112, U.S.A. 
background composition. A representative field was selected and all cells in that field (at $\times 200)$ were counted and recorded according to cell shape and nucleus size (epithelial cells) and number (leucocytes). The percentage of each cell type was calculated.

The colour and oedema of the genitalia were also recorded according to the following subjective scales: dark, medium, light and pale pink coloration; not, low, medium and high swollen.

\section{Results}

\section{Vaginal cytology}

There was a regular pattern of changes in the cell types in the vaginal smears. Non-cornified epithelial cells (oval shape with a nucleus covering more than half the cell area) were found associated with clumps of leucocytes and much mucus. As the epithelial cells began to show signs of cornification (change in shape from oval to irregular, reduced nuclear size), the few scattered leucocytes eventually disappeared. Fully cornified cells (irregularly shaped with small sized-or absent nuclei) were found when there was a background of bacteria and cellular debris, but no leucocytes. An invasion of leucocytes, at first scattered and then clumped into 'islands', occurred as non-cornified cells appeared again; when these cells outnumbered cornified cells, the leucocytes again formed aggregates with them. No erythrocytes were ever seen in the vaginal smears.

\section{External genitalia}

Fluctuations in coloration and tumescence of the external genitalia paralleled the vaginal cytological changes. Although colour was a highly individual indicator, a general trend was seen in all the animals, changing from light to dark and back again. The darker shades (medium and dark pink) were associated with low or unswollen genitalia, while the lighter shades (pale and light pink) occurred with medium and high tumescence.

\section{External discharge of mucus}

Mucus was sometimes found in and around the vaginal orifice at the time of full epithelial cell cornification and for a few days during the non-cornified cell/leucocyte stage. The colour of the mucus was white, yellow or green; white mucus occurred before leucocytes were present in the vaginal smear, white, yellow or green mucus was associated with leucocyte invasion, and yellow mucus predominated after the leucocytes had returned.

Although all 8 experimental females showed this discharge of mucus at some time during the year, those in Group B (with visual contact) showed mucous cycles for about $90 \%$ of the time, with 3 of the 4 animals displaying mucus at every cycle and the other producing mucus in 4 of her 7 cycles. In contrast, the lemurs in Group A (without visual contact) showed mucus in only $60 \%$ of all cycles, but the difference was not statistically significant. The female housed with a male did not exhibit a mucous discharge in any of her 7 cycles.

\section{Cycle length}

As indicated above, there are several potential indices with which to estimate oestrous cycle length: vaginal epithelial cell cornification, appearance and disappearance of leucocytes, genital coloration and oedema, and occurrence of external mucus. The latter index is not a predictable event among individuals, and its value is mainly supplementary.

Individual and group mean cycle lengths for the 8 females are given in Table 1. There was no significant difference among the three criteria, or between the two groups, when analysed by a single classification analysis of variance; therefore, these provide reliable and comparable measures of the cycle length, which is $29-30$ days. The 9 th female had a mean cycle length of 28.33 days.

\section{Seasonality}

The 8 lemurs exhibited 68 cycles during the 12 months of the study, for an average of 8.5 cycles each (see Table 1). Cycles occurred from September to July, but the pattern of cycling differed for the two groups studied. All 4 Group A females exhibited a September cycle, but each then became 
irregular in October and November, and regular cycles began only in December. The Group B females began regular cycling in November; only 2 of them had had one cycle each before November, whereas all 4 Group $A$ females had had two cycles each before November. Because of this difference in the onset of regular cycles, Group A females exhibited significantly more cycles/female than did those females in Group B (9.5 versus $7.5 ; P<0.001)$. There was no difference between the two groups in the cessation of cycles. One female continued cycles until early July, but the other 7 lemurs had their last cycles in April, May or June.

Table 1. Determination of oestrous cycle length (days \pm s.d.) in captive brown lemurs according to three different criteria

\begin{tabular}{|c|c|c|c|c|c|}
\hline \multirow[b]{2}{*}{ Lemur } & \multirow[b]{2}{*}{$\begin{array}{c}\text { No. } \\
\text { of cycles }\end{array}$} & \multicolumn{2}{|c|}{ Vaginal smear } & \multirow[b]{2}{*}{$\begin{array}{l}\text { Tumescence and } \\
\text { colour of genitalia }\end{array}$} & \multirow[b]{2}{*}{$\begin{array}{c}\text { Mean cycle } \\
\text { length }( \pm \text { s.e.m) }\end{array}$} \\
\hline & & $\begin{array}{l}\text { Maximal } \\
\text { cornification }\end{array}$ & $\begin{array}{l}\text { Return of } \\
\text { leucocytes }\end{array}$ & & \\
\hline \multicolumn{6}{|l|}{ Group A } \\
\hline AI & 10 & $26 \cdot 5 \pm 5 \cdot 8$ & $27 \cdot 0 \pm 2 \cdot 2$ & $26 \cdot 2 \pm 2 \cdot 3$ & $26.9 \pm 0.2$ \\
\hline $\mathrm{A} 2$ & 9 & $28 \cdot 3 \pm 2 \cdot 6$ & $28 \cdot 4 \pm 3 \cdot 1$ & $28 \cdot 7 \pm 5 \cdot 1$ & $28.5 \pm 0.1$ \\
\hline A3 & 8 & $31 \cdot 1 \pm 4 \cdot 1$ & $28.7 \pm 1.4$ & $28.0 \pm 2.2$ & $29.3 \pm 0.9$ \\
\hline A4 & 11 & $30 \cdot 4 \pm 9 \cdot 2$ & $30 \cdot 2 \pm 8 \cdot 5$ & $31 \cdot 0 \pm 5 \cdot 1$ & $30.5 \pm 0.2$ \\
\hline Mean \pm s.e.m. & $9 \cdot 5$ & $29 \cdot 1 \pm 1 \cdot 1$ & $28 \cdot 6 \pm 0.7$ & $28 \cdot 5 \pm 1 \cdot 0$ & $28.8 \pm 0.8$ \\
\hline \multicolumn{6}{|l|}{ Group B } \\
\hline B1 & 8 & $29.6 \pm 3.6$ & $31 \cdot 0 \pm 2.8$ & $28 \cdot 1 \pm 2 \cdot 5$ & $29.6 \pm 0.8$ \\
\hline B2 & 8 & $30.2 \pm 3.7$ & $29 \cdot 7 \pm 4.5$ & $30.6 \pm 2.9$ & $30.2 \pm 0.3$ \\
\hline B3 & 7 & $30 \cdot 2 \pm 6 \cdot 3$ & $30 \cdot 6 \pm 2 \cdot 7$ & $29.6 \pm 3.2$ & $30.1 \pm 0.3$ \\
\hline B4 & 7 & $31 \cdot 5 \pm 3 \cdot 1$ & $31 \cdot 5 \pm 4.9$ & $30 \cdot 0 \pm 4 \cdot 6$ & $31.0 \pm 0.5$ \\
\hline Mean \pm s.e.m. & $7 \cdot 5$ & $30.4 \pm 0.4$ & $30.7 \pm 0.4$ & $29.6 \pm 0.5$ & $30.2 \pm 0.3$ \\
\hline \multicolumn{6}{|l|}{ Overall mean } \\
\hline 土s.e.m. & $8 \cdot 5$ & $29 \cdot 7 \pm 0.6$ & $29.6 \pm 0.5$ & $29 \cdot 0 \pm 0.6$ & $29.5 \pm 0.5$ \\
\hline
\end{tabular}

After the last cycle, anoestrus lasted for about 3 months. Two vaginal smear patterns were seen in anoestrous animals. One was a smear containing irregularly shaped epithelial cells with medium-sized nuclei, no leucocytes or leucocytes scattered or in small clumps. The other smear type contained rounded epithelial cells and aggregations of leucocytes. Medium amounts of mucus were present with both types and an external mucous discharge was seen sporadically throughout the anoestrous period. Individual animals sometimes showed both types of smears, but only in succession for 1 or 2 months with a few transitional days between. No trends could be detected in the appearance of the two types of vaginal smears in anoestrous lemurs.

\section{Discussion}

Studies on reproductive cycles of other primate species, notably macaques, have demonstrated the interrelations among vaginal cytology, hormonal fluctuations, sex skin swelling and coloration, and ovarian state (e.g. Hamlett, 1939; Mahoney, 1970; Ando, Nigi \& Ohsawa, 1973; McArthur, Ovadia, Smith \& Bashir-Farahmand, 1972; Saladrini, Spieler \& Coppola, 1972; Czaja, Eisele \& Goy, 1975; Halbert, Tam, Adams \& Blandau, 1976). Briefly, ovulation is associated with cornified vaginal smears, a peak of oestrogen secretion, and maximal tumescence and reddening of the genital region (in species which display genital fluctuations). Furthermore, ovulation is associated with behavioural receptivity and conception. Animals which copulate throughout the oestrous cycle generally show an increase in the frequency of sexual behaviour around ovulation. After oestrus, the luteal phase is characterized by non-cornified cells in the vaginal smears, increasing levels of progesterone, and 
decreasing tumescence and coloration. The formation of a corpus luteum and occurrence of menstruation vary with species. The follicular phase involves cornifying vaginal cells, increasing oestrogen secretion, sex skin oedema and coloration, and maturation of ovarian follicles.

The only prosimian primate for which these details of the female reproductive cycle have been worked out is the bush-baby Galago crassicaudatus (Eaton, Slob \& Resko, 1973) and the pattern of cytological and hormonal changes is similar to that of macaques. The present observations of brown lemurs show that the cycles of these animals are similar to those of macaques and G. crassicaudatus. Oestrus is typified by a vaginal smear, lasting for about 11 days, which contains cornified cells, bacteria and no leucocytes, and is accompanied by medium-high swollen and pale-light pink genitalia. Metoestrus lasts for 2-3 days and is indicated by the leucocytic invasion and the presence of irregularly shaped epithelial cells with medium-sized nuclei and cornified celis as well as a lot of mucus. Genital swelling is reduced and the genitalia become darker. Dioestrus, lasting for about 15 days, is characterized by non-cornified cells surrounded by leucocytes, and low or not swollen genitalia which are medium and dark pink in colour. Pro-oestrus lasts for 2-3 days and is indicated by disappearing leucocytes and cornified epithelial cells, increased tumescence and lighter genital colour.

The presence of bacteria in the smears at oestrus could represent a potential source of odour (see Leon, 1974) associated with olfactory communication of female reproductive status. The production of a mucous discharge and other vaginal secretions might serve a similar function (see Michael \& Keverne, 1968, 1970; Michael, Bonsall \& Zumpe, 1976). The colour change in mucus and the coloration and tumescence of the genitalia may provide visual cues.

In my captive lemurs, oestrous cycles occurred throughout most of the year, from September to July, although $L$. fulvus has a restricted breeding season of 1-2 months in the wild (Petter-Rousseaux, 1968; Harrington, 1971, 1975). At the Duke University Primate Facility, conceptions occur primarily in November and December, with a range from October to January. Most prosimian seasonal breeders are polyoestrous (Petter-Rousseaux, 1962, 1964; Van Horn \& Eaton, 1978), but 8 cycles is the largest number so far recorded for a female in one season. Although the two groups differed in the timing of the onset of regular cycles, the housing conditions are probably not the reason for the length of the cyclic period because data for another year on the same females living in social groups revealed the same pattern (Boskoff, 1978). It was not possible to be certain that the lemurs were ovulating in each cycle. The cycles from November to March differed from those earlier and later in that the palest colour and greatest tumescence of the genitalia occurred in this 5 -month period and there was a more distinctive regularity in vaginal smear changes. Possibly only these cycles were ovulatory.

There was no difference among animals or between groups with respect to changes in vaginal cytology, coloration and swelling of genitalia, and cycle length. All females showed a similar cycle length of 30 days regardless of age, reproductive history, and current housing. There were, however, several differences between the two groups which may reflect the housing conditions. For example, apart from differences in the time of onset of cycling, the number of cycles exhibited over the year, and the occurrence of a mucous discharge, the females in Group B, who were allowed visual contact, exhibited synchrony of oestrus while the females in Group A, who were prevented visual contact, did not (see Boskoff, 1976, for discussion). The reasons for these differences are unclear, but the effect of the housing conditions on lemur reproductive cycles is of interest.

The present data on the $L$. fulvus oestrous cycle provide a comparison with previous information on lemurs. Behavioural data also indicate a 30-day cycle for $L$. fulvus (Cowgill et al., 1962; Harrington, 1971; Vick, 1977), and are consistent with recorded cycle lengths of 30-40 days for other Lemur species; e.g. 39 days in L. catta (Evans \& Goy, 1968), 40 days (Bogart et al., 1977a) and 30 days (Boskoff, 1977) for L. variegatus, 30-33 days in L. macaco (Bogart et al., 1977a) and 37 days in $L$. mongoz (Evans \& Goy, 1968). The seasonality of captive lemurs is known to differ. $L$. catta females show about 3 cycles each from October to February (Evans \& Goy, 1968), while L. variegatus has only 2 oestrous periods in January and February (Boskoff, 1977; Bogart et al., 1977a). L. fulvus, as seen here, may cycle 8 times. The duration of receptivity also varies, being 1 day or less for L. catta (Jolly, 1966, 1967; Evans \& Goy, 1968), 2 days for L. fulvus (Boskoff, 1978), 4 days for L. macaco (Bogart et al., 1977a), and 5-6 days for $L$. variegatus (Boskoff, 1977; Bogart et al, 1 1977a).mThe 112day period 
when the vaginal smears indicated oestrus in L. fulvus is much longer than that of 5 days reported for L. catta (Evans \& Goy, 1968).

There are, therefore, differences in many aspects of reproduction in Lemur species, including not only features of the oestrous cycle, but also gestation duration, litter size and maternal behaviour (see Klopfer \& Boskoff, 1978). This intrageneric variability in Lemur mirrors the variability found in all prosimian primates, and provides a stimulus for further research.

This study was part of an M.A. thesis, Duke University, supported in part by grant number MH04453 to Dr P. Klopfer. I thank Mr D. Anderson, Dr J. Bergeron, and Mr C. Bittle of the Primate Facility for their help, and Dr C. Erickson and Dr P. Klopfer for their advice and support.

\section{References}

ANdo, A. Nigl, H. \& OHSAWA, N. (1973) Urinary estrogens as an index for estimating the time of ovulation. Exp. Animals 22, 479-487.

Bogart, M.H., CoOPER, R.W. \& Benirschke, K. (1977a) Reproductive studies of black and ruffed lemurs (Lemur macaco macaco and L. variegatus ssp). Int. Zoo Yearbook 17, 177-182.

Bogart, M.H., Kumamoto, A.T. \& LAsLey, B.L. (1977b) A comparison of the reproductive cycle of three species of Lemur. Folia primatol. 28, 134-143.

BosKoFF, K.J. (1976) Indicators of reproductive cyclicity in the prosimian primate, Lemur fulvus: an analysis of vaginal and genital changes. M.A. thesis, Duke University.

Boskoff, K.J. (1977) Aspects of reproduction in ruffed lemurs (Lemur variegatus). Folia primatol. 28, 241250.

Boskoff, K.J. (1978) Behavioral fluctuations in Lemur fulvus: within and without the breeding season. In Recent Advances in Primatology, Vol. 3. Eds D. J. Chivers \& J. Herbert. Academic Press, London.

BudnITZ, N. \& DaINIS, K. (1975) Lemur catta: ecology and behavior. In Lemur Biology, pp. 219-235. Eds I. Tattersall \& R. W. Sussman. Plenum Press, New York.

Chandler, C.F., JR (1975) Development and function of marking and sexual behavior in the Malagasy prosimian primate, Lemur fulvus. Primates 16, 35-47.

Cowgill, U.M., Bishop, A., ANDrew, R.J. \& HutchinsoN, G.E. (1962) An apparent lunar periodicity in the sexual cycle of certain prosimians. Proc. natn. Acad. Sci. U.S.A. 48, 238-241.

CzajA, J.A., Eisele, S.G. \& Goy, R.W. (1975) Cyclical changes in the sexual skin of female rhesus: relationships to mating behaviour and successful artificial insemination. Fedn Proc. Fedn Am. Socs. exp. Biol. 34, 1680-1684.

Eaton, G.G., Slob, A. \& Resko, J.A. (1973) Cycles of mating behaviour, oestrogen and progesterone in the thick-tailed bushbaby (Galago crassicaudatus crassicaudatus) under laboratory conditions. Anim. Behav. 21, 309-315.

Evans, C.S. \& GoY, R.W. (1968) Social behaviour and reproductive cycles in captive Ring-tailed lemurs (Lemur catta). J. Zool., Lond. 156, 181-197.

Halbert, S.A., TAM, P.Y., Adams, R.J. \& Blandau, R.J. (1976) Detection of ovulation in the pigtail monkey with an implantable optical transducer. Gynec. Invest. 7, 41.
Hamletr, G.W.D. (1939) Reproduction in American monkeys. I. Estrous cycle, ovulation and menstruation in Cebus. Anat. Rec. 73, 171-187.

HARRINGTON, J.E. (1971) Olfactory communication in Lemur fulvus. Ph.D. dissertation, Duke University.

HARRINGTON, J.E. (1975) Field observations of social behavior of Lemur fulvus fulvus E. Geoffroy 1812 . In Lemur Biology, pp. 259-279. Eds I. Tattersall \& R. W. Sussman. Plenum Press, New York.

Jolly, A. (1966) Lemur Behavior: a Madagascar Field Study. University of Chicago Press.

JoLLY, A. (1967) Breeding synchrony in wild Lemur catta. In Social Communication among Primates, pp. 3-14. Ed. S. A. Altmann. University of Chicago Press.

KLopfer, P.H. \& BoskofF, K.J. (1978) Maternal behavior in prosimians. In The Study of Prosimian Behavior, pp. 123-156. Eds G. A. Doyle \& R. D. Martin. Academic Press, New York.

Leon, M. (1974) Maternal pheromone. Physiol. Beh. 13, $441-453$.

MahoNeY, C.J. (1970) A study of the menstrual cycle in Macaca irus, with special reference to the detection of ovulation. J. Reprod. Fert. 21, 153-163.

Mcarthur, J.W., Ovadia, J., Smith, O.W. \& BashirFarahmand, J. (1972) The menstrual cycle of the bonnet monkey (Macaca radiata). Folia primatol. 17, 107-121.

Michael, R.P. \& KeVerne, E.B. (1968) Pheromones in the communication of sexual status in primates. Nature, Lond. 218, 746-749.

Michael, R.P. \& Keverne, E.B. (1970) Primate sex pheromones of vaginal origin. Nature, Lond. 225, 84-85.

Michael, R.P., Bonsall, R.W. \& Zumpe, D. (1976) Evidence for chemical communication in primates. Vitams Horm. 34, 137-186.

Petter, J.J. (1972) Recherches sur l'ecologie et l'ethologie des lémuriens malgaches. Mém. Mus. natn. Hist. nat., Paris, $A$ 27, 1-146.

Petter, J.J. (1965) The lemurs of Madagascar. In Primate Behavior, pp. 292-319. Ed. I. DeVore. Holt, Rinehart \& Winston, New York.

Petter-Rousseaux, A. (1962) Recherches sur la biologie de la reproduction des primates inferieurs. Mammalia 26, Suppl. 1, 1-88.

PetTer-Rousseaux, A. (1964) Reproductive physiology and behavior of the Lemuroidea. In Evolutionary and Genetic Biology of Primates, Vol. II, pp. 91-132. Ed. J. Buettner-Janusch, Academic Press, New York. 
Petter-Rousseaux, A. (1968) Cycles génitaux saisonniers des lémuriens malgaches. Entretiens de Chizé, Serie Physiologie No. 1, 11-22.

REYNOLDS, R.L. \& VAN HORN, R.N. (1977) Induction of estrus in intact Lemur catta under photoinhibition of ovarian cycles. Physiol. Behav. 18, 693-700.

Saldarini, R.J., Spieler, J.M. \& Coppola, J.A. (1972) Plasma estrogens, progestins and spinnbarkeit characteristics during selected portions of the menstrual cycle of the cynomolgus monkey (Macaca fascicularis). Biol. Reprod. 7, 347-355.

Sussman, R.W. (1972) An ecological study of two Madagascan primates: Lemur fulvus rufus and Lemur catta. Ph.D. dissertation, Duke University.

Sussman, R.W. (1975) A preliminary study of the behavior and ecology of Lemur fulvus rufus Audebert
1800. In Lemur Biology, pp. 237-258. Eds I. Tattersall \& R. W. Sussman. Plenum Press, New York.

VAN HORN, R.N. (1975) Primate breeding season: photoperiodic regulation in captive Lemur catta. Folia primatol. 24, 203-220.

VAN HORN, R.N. \& EATON, G.G. (1978) Reproductive physiology and behavior in prosimians. In The Study of Prosimian Behavior. Eds G. A. Doyle \& R. D. Martin. Academic Press, New York.

VICK, L.G. (1977) The role of interindividual relationships in two troops of captive Lemur fulvus. Ph.D. dissertation, University of North Carolina, Chapel Hill.

Vick, L.G. \& ConleY, J.M. (1976) An ethogram for Lemur fulvus. Primates 17, 125-144.

Received 1 March 1978 